\title{
The Girls Who Waited? Female Companions and Gender in Doctor Who
}

Lorna Jowett

\begin{abstract}
:
Science fiction has the potential to offer something new in terms of gender representation. This doesn't mean it always delivers on this potential. Amid the hype surrounding the $50^{\text {th }}$ anniversary of Doctor Who, the longest running science fiction series on television, a slightly critical edge is discernable in the media coverage concerning the casting of the twelfth Doctor and issues of representation in the series. This paper examines Doctor Who in the broader context of TV drama and changes to the TV industry, analysing the series' gender representation, especially in the 2005 reboot, and focusing largely on the female 'companions'.
\end{abstract}

Keywords: gender representation, television, feminism, BBC.

When I put together an earlier version of this paper two years ago, I discovered a surprising gap in the academic study of Doctor Who around gender. Gender in science fiction has often been studied, after all, and Star Trek, another science fiction television series starting in the 1960s (original run 1966-69) and continued via spin-offs and reboots, has long been analysed in terms of gender. So why not Doctor Who? Admittedly, Doctor Who's creators have no clear philosophy about trying to represent a more equal society, as with the utopian Trek. The lack of scholarship on gender in Doctor Who may also be part of a lack of scholarship generally on the series-academic study of it is just gaining momentum, and only started to accumulate seriously in the last five years. Earlier book-length studies (such as those by Kim Newman and James 
Chapman) as well as more recent monographs (by Matt Hills, Piers Britton and others) take a broad approach, so have little time to analyze gender in detail. John Tulloch's work on Doctor Who audiences ${ }^{1}$ likewise only touches on gender issues as part of a wider study of reception and fandom.

The 2005 reboot has led to some analysis of the new, prominent and almost exclusively female, companions. 2010's Ruminations, Peregrinations, and Regenerations: A Critical Approach to Doctor $W h o^{2}$ includes a four-chapter section titled 'Companions: Gender and Race,' for example, and Gillian Leitch's collection Doctor Who in Time and Space (2013) features three chapters on gender focused on companions. Some analysis of masculinity is also emerging, though less has been published to date. The most notable area being tackled in terms of gender is fandom, and much of this work (by Rebecca Williams, Brigid Cherry and others) examines how audiences for the reboot have challenged male-dominated Doctor Who fandom in UK. The most extensive coverage of gender under a single title comes in two volumes Chicks Dig Time Lords (2010) and Chicks Unravel Time (2012) which range across the whole series but, like some other notable studies of Doctor Who, these are not strictly scholarly.

Given that a television series as long-lived as Doctor Who, which began in the 1960s but has been rebooted in the twenty-first century, clearly has to address changing attitudes to gender, there is much to be said about how the series negotiates such change. Science fiction, because it deals with the novel and the strange, has the potential to offer something new in terms of gender representation. This doesn't mean it always delivers on this potential, of course. Doctor Who, as well as being science fiction with cult status and a large fan following, is also, especially in its current incarnation, a mainstream TV drama from a public service broadcaster. It airs on Saturday night in an 
early prime-time slot and attracts a family audience. Thus Doctor Who negotiates tricky issues of gendered identity in genre television (science fiction and action adventure) for different audiences (cult and mainstream), in ways that a series like Star Trek did not (or did not do as consciously, as it was intended from the outset to be intelligent science fiction for adult audiences, moving science fiction television away from perceptions of juvenile consumers).

New Doctor Who has come under public attack for unequal representation as it reaches its 50th anniversary, most openly in debates around casting a new actor to take over from Matt Smith as the Doctor. Doctor Who offers itself as a fascinating case study of the developing nature of television drama in relation to gender representation and to shifts in the production and reception of television drama. 'Television fiction, striving to remain relevant and credible to audiences, must negotiate questions of identity that change as understanding of ourselves and our society changes. ${ }^{3}$ Doctor Who has inevitably had to do this in the course of its 50 -year run. The 2009 BBC book, Doctor Who: Companions and Allies notes that when Jo Grant (Katy Manning) left the show in 1973 'the Doctor Who team realised that the series needed to reflect significant changes in society at large' and introduced Sarah Jane Smith (Elisabeth Sladen), as a 'more independent and self-sufficient character. ${ }^{4}$ Yet while the 'nowness' of TV requires it to keep up with shifting views of gender and identity, its mainstream address can limit representations. John Tulloch's work with Doctor Who audiences suggests that Sarah Jane did not entirely fulfil the aims outlined above. One of Tulloch's respondents comments that 'she is [the Doctor's] underling'; another observes, 'Sarah seems very tokenish given that she's the one who's meant to be the feminist' ${ }^{5}$ Hannah Hamad observes that the series' 'revivification in a postfeminist context, and renewed recourse to the female companion as the principal means of representing femininity was always 
going to be noteworthy from a feminist critical standpoint. ${ }^{6}$ This paper cannot chart the whole of gender representation in Doctor Who. Instead it focuses on how the reboot tries to make its representations culturally relevant as well as acceptable to contemporary audiences. I try to give some sense of development and comparison with the classic series, but necessarily have to select only a few examples from the vast array on offer.

Commentators and scholars have noted that female companions in particular have a 'decorative' function in the series. 'They've all been very sort of passive,' comments another of Tulloch's respondents, 'They're just there for window dressing, obviously'. ${ }^{7}$ Jennifer Pelland even quotes Doctor Who producer John Nathan-Turner on companion Peri (Nicola Bryant 1984-86): 'She'll often be wearing leotards and bikinis. A lot of Dads watch Doctor Who and I'm sure they will like Nicola. ${ }^{8}$ Of course, other science fiction TV has struggled with similar contradictions. Star Trek offered a supposedly egalitarian society in the Federation, yet the appearance and costuming of its 1960s female characters, especially the guest stars, suggested that conventional notions of femininity still impacted on what women could do and be in the show. Doctor Who may be structured around non-conformity, personal liberty, and individualism but these are valorised in the Doctor while companions tend to get more 'normative treatment'.

From the very first episodes of Doctor Who, the focus is on the reactions of teachers Barbara (Jacqueline Hill) and Ian (William Russell) to the strange new worlds they encounter upon investigating 'Unearthly Child' Susan (Carole Ann Ford) and being whisked away in the TARDIS by her grandfather, the Doctor (William Hartnell). Companions therefore serve a dual role as focaliser of the action and vehicle for the sense of wonder associated with the science fiction genre. Richard Wallace cites writer and script editor Terrance Dicks' notion that the Doctor Who companion is 'a plot 
device first and foremost and a character second'. ${ }^{10}$ This has changed as TV drama has evolved. Even in fantasy, horror, and science fiction, where once the spectacle of the fantastic was foregrounded, now genre television places 'emphasis on the reactions of characters to the unknown over the representation of the fantastic itself,' with close ups on facial expressions replacing action or special effects in cliff-hangers (original emphasis). ${ }^{11}$

Doctor Who companions are important to the show's success. More characters allow for more variety and set up more narrative possibilities. In contemporary TV drama, character interactions also afford narratives that resist closure, typically running alongside self-contained episodes or season story arcs. This has been incorporated into the relaunched Doctor Who, which has many of the hallmarks of 'quality' serial TV drama such as season arcs and complex narrative structures, backstory supporting character development and emotional realism, and distinctive visual style, as exemplified by American shows like Buffy the Vampire Slayer (1997-2003).

However, the structure and premise of Doctor Who present some difficulty for its representation of gender. While it is undeniable that, as Lynette Porter notes, the new companions all 'develop unique relationships with their Doctor(s) and make the role of companion more dynamic — and more acceptable to female viewers,' even to the point that the Doctor 'also surprisingly becomes emotionally affected by his companions, ${ }^{, 12}$ the Doctor is the main character, the focus, and the hero. Other characters necessarily function as sidekicks or adjuncts and 'the role of companion clearly means a secondary role, with the Doctor forever being the superior character. ${ }^{13}$ This structure is rather different to ensemble cast drama which does not privilege one character but focuses on a group. There have been a few new Who episodes that are referred to as 'Doctor-lite' stories (such as 'Love and Monsters' 2:10, 'Blink' 3:10, 'Turn Left' 4:11 and maybe 
'The Girl Who Waited' 6:10) but generally the Doctor is the stable point around which the drama revolves. While the actor portraying him changes (allowing the production team to do something new and different with the character), the companions change more frequently and, once they leave the TARDIS and the Doctor, we generally see nothing more of them. ${ }^{14}$

But a mainstream TV product does not necessarily have to conform to conventional gender structures even if it is stuck with a premise that seems to uphold them. BBC One's other recent prime time family dramas like Merlin (2008-2013) and Robin Hood (2006-2009) had to negotiate this too, often attempting to impose twentyfirst century models of gender on stories that are, however loosely, set in earlier historical periods and focus on male heroes. Robin Hood, Merlin and Doctor Who can be seen as indicative of cultural attitudes about gender. Christopher Eccleston, David Tennant and Matt Smith playing the Doctor all offer different versions of masculinity and heroism just as the various female companions offer a range of femininities. Britton argues fairly convincingly that aspects of the new Doctor Who mount a sustained critique of traditional gender dynamics and structures. ${ }^{15}$ The character of the Doctor has always been an unconventional hero: Williams notes that David Tennant's tenth Doctor seems to embody geek chic, ${ }^{16}$ and the Doctor is a particularly British hero. This disruption of standard action heroism can be seen as attractive to a female audience. In an article titled 'David Tennant's Bum', Laura Mead's main argument for enjoying Doctor Who is, 'I am tired of machismo, but I am not tired of men.'17

Yet, as an alien, the Doctor is bound to remain a fairly mysterious figure and thus the burden of characterization falls upon the companions. In simple terms, this means companions now have backstories, families and in some cases even dependents of their own. While Tegan Jovanka (Janet Fielding) may have been 'the first companion 
to have various family members appear in the show, ${ }^{, 18}$ this is the case for all the contemporary female companions. The first, Rose (Billie Piper), fits the typical companion pattern of seeking adventure with the Doctor, yet she also has a mother and a boyfriend at home. When Rose discovers that boyfriend Mickey (Noel Clarke) is still alive after encountering his plastic replacement during an attack by the Autons ('Rose' 1:1), she is shocked that the Doctor never mentioned 'that was always a possibility.' 'You knew that,' she asks, 'and you never said?' with the implication that he has been insensitive to her feelings. 'Can we keep the domestics outside, please?' he responds, but the new approach to the companions guarantees that 'domestics' regularly feature. Although Rose chooses travelling with the Doctor over staying at home with Mickey and her mum Jackie (Camille Coduri), she often communicates with them and returns home for visits. Likewise, Martha (Freema Agyeman), Donna (Catherine Tate), and Amy (Karen Gillan) all have people close to them who are either left behind or persuaded to join in.

While the Doctor is lonely or at least solitary, the female companions are defined by relationships. ${ }^{19}$ Even Donna, who shows the least romantic interest in the Doctor, is characterized through her somewhat antagonistic relationship with a critical mother, and by a much warmer and supportive bond with granddad Wilf (Bernard Cribbins), as established in 'Partners in Crime' (3:1). These relationships afford companions more depth than before, and Leslie McMurtry observes that the emotional intelligence of new Who affected fan perception and production, and 'caused some female fans to abandon "gender-blind" and invest more of their femininity in their [fan] writing. ${ }^{, 20}$ However, such relationships situate the female companions within traditionally feminine networks of family, the domestic and relationship building. Antoinette Winstead goes so far as to state that Rose, Martha and Donna 'despite class 
and ethnicity, are limited and constrained by their assigned familial roles—roles they wish to escape. ${ }^{21}$ Even Clara (Jenna Coleman), the mystery, is carer to two children, Angie and Artie Maitland.

The relaunched show also changes the nature of the Doctor's relationships with his female companions. The Doctor used to be, at least on the surface, asexual. ${ }^{22} \mathrm{Kim}$ Newman points to 'the never-quite-tackled possibility of romantic, perhaps unethical, liaisons between the Doctor and his attractive female companions, ${ }^{23}$ in the old series. A 2005 article from Doctor Who Magazine cited by McMurtry suggests lack of romance in the classic series 'freed girls to try other things'. ${ }^{24}$ Traditional heterosexual romance is to the fore in the reboot from the start, however, and although Matt Hills argues that "new Who is premised on an avoidance of normative heterosexual "social practice" such as settling down or child-rearing, ${ }^{, 25}$ Hamad identifies its simultaneous and 'marked thematic turn towards romantic relationships and sexual tensions. ${ }^{26}$

Britton's rather hostile reading of the Russell T. Davies era identifies unresolved sexual tension as a key strategy that works to the detriment of female characters. ${ }^{27}$ Yet unresolved sexual tension is a common convention in serial TV drama, for obvious reasons. Romance tends to signal closure; unresolved sexual tension allows for ongoing seriality. In a restricted circle of characters and a tense environment, also typical in TV, it simply heightens the drama. Hills' observation that Martha's arc is another version of the unrequited love story re/written by Davies, with the Doctor as a version of Stuart from 1999 series Queer as Folk ${ }^{28}$ may explain the derivation of this pattern, but does not mitigate the way it undercuts Martha's character. Given the potential Martha has, especially in terms of intersections of race, class and gender, this is disappointing. As Britton points out, the use of unrequited love in Doctor Who situates both Rose and 
Martha effectively 'in the Doctor's erotic thrall ... defined ... primarily in terms of his sexual desirability' (my emphasis). ${ }^{29}$

Emphasis on both unfulfilled romance and loving families at home highlights the way the Doctor rips companions away from 'normal' life and then dumps them back into it, usually (in the reboot) when he, not they, decide. The new series emphasizes how the Doctor is a lonely traveler in need of friendship, and at times uses the female companions to mount strong critiques of the way he achieves this. Each new companion thinks herself 'special' and unique, when she is simply the latest in a long series. A cartoon widely reproduced on the internet titled 'Doctor's Girls' by mimi-na/ Amy Mebberson encapsulates this perfectly: it shows a line of companions starting with Susan and moving through to Rose, standing beside the tenth Doctor, exclaiming, 'OhMiGod I thought I was special!!' ${ }^{30}$ Moreover, when Donna is mysteriously transported from her wedding to the TARDIS in 'The Runaway Bride' (3:0 Christmas special), she accuses the Doctor of doing this deliberately and, seeing a jacket left by Rose, asks angrily 'I'm not the first am I? How many women have you abducted?' Comments like this suddenly estrange our view of the Doctor as benevolent and make his behaviour much more sinister. ${ }^{31}$

The notion of abandonment and damage is revisited several times in the new Doctor Who, as with the return of Sarah Jane in 'School Reunion' (2:3). Britton describes this episode as a critique of the Doctor's 'serial monogamy' and argues that it 'would surely not have been so potent with any other companion but Sarah.' ${ }^{32}$ Meeting the tenth Doctor when they both investigate the same mysterious incident, Sarah is at first excited and then hurt: 'Did I do something wrong? Because you never came back for me. You just—dumped me.' Here the age and gender dynamic from the classic series is reversed: Sarah Jane is no longer the youthful sidekick of a mature Doctor, she 
is a mature, ageing female meeting a younger-seeming Doctor. Her acute awareness of the difference in their apparent ages is reinforced: 'You look incredible,' she tells him. 'So do you,' he responds but she replies flatly, 'I got older.' This is why the Doctor is a lonely hero- he travels through time, and is able to regenerate into a new body, rather than plodding along a linear timeline and ageing physically as humans do. The new series has often emphasized the Doctor's age and his vast store of experiences, as in the eleventh Doctor's speech in Rings of Akhaten (7:7): 'I saw the birth of the universe and I watched as time ran out, moment by moment, until nothing remained .... I've seen things you wouldn't believe. I've lost things you will never understand.' 'School Reunion' gives us a slightly different, more deflating perspective on the Doctor's ageing. 'You can tell you're getting older. Your assistants are getting younger,' Sarah Jane snipes when she sees Rose for the first time.

Although Sarah Jane now decides to give up pining for the Doctor and make her own life in The Sarah Jane Adventures (2007-11), the Doctor's appearances in the spinoff reinforce the emotional damage inflicted on his companions. This is again emphasized when Jo Grant also returns during 2010's 'Death of the Doctor' (The Sarah Jane Adventures 4:5 and 4:6) and she too talks about expecting the Doctor to at least visit after she left the TARDIS. ${ }^{33}$ Seanan McGuire comments that 'The story of the women of Series Five is an old one, as old as Penelope and Odysseus. It is a story of waiting. ${ }^{34}$ This process starts somewhat sooner that McGuire notes, however, and both Sarah Jane and Jo are seen to have aged as they waited for just a short visit with the Doctor. Thus recurring structures in the series position women as passively waiting and ageing, while the male hero actively travels and avoids settling down, or even visiting those companions who have chosen to do so, as well as remaining physically young. ${ }^{35}$ 
The linked themes of abandonment and waiting reach a peak in 2011's 'The Girl Who Waited' (Doctor Who 6:10) when Amy is left to fend for herself in a quarantine camp for decades, growing old alone in an accelerated time stream after she is separated from Rory (Arthur Darvill) and the Doctor. Episode reviews implied that the emotional impact of this character-centred episode was new territory for the series. Certainly, Old Amy's bitterness about the Doctor is highlighted and was given prominence in the website's page on the episode at the time: 'Don't lecture me, blue box man, flying through time on whimsy. All I've got, all I've had for 36 years is cold, hard reality.' Here, as with Sarah Jane in 'School Renuion,' we see the physical ageing of a female companion contrasted with the youth of the time-travelling Doctor: the girl who waited for the two men in her life to rescue her waits until she becomes an older woman. Every time we see Old Amy it highlights the Doctor's alien experience of time in comparison with human mortality. Here Rory and the Doctor have to choose whether to sacrifice Old or Young Amy, since only one can return to the TARDIS. The displacement of sacrifice and abandonment onto a new version of a familiar character affects the impact of this storyline, but also sets it at sufficient distance for the choice made and the sense of fruitless waiting to be presented very starkly. The Doctor's tendency to abandon companions and the lasting trauma they feel, take centre stage in this episode.

In their books on Doctor Who, Britton, Newman, and Chapman all tend to agree that the companions basically provide contrast to the Doctor. The Doctor is active and/or intellectual, independent, lonely (or at least solitary) and heroic. Companions, especially female companions, tend to be emotional, passive or dependent so the Doctor can function as their champion and rescuer. The inequality between the Doctor and his companions was not endemic in TV of the 1960s-both Newman and Chapman point to Cathy Gale (Honor Blackman) and then Emma Peel's (Diana Rigg) more equal 
partnership with John Steed (Patrick Macnee) in The Avengers (1961-69). ${ }^{36}$ The succession of Doctor Who companions also offered some potential equals, such as Romana (Mary Tamm), another Time Lord, or scientist Dr. Liz Shaw (Caroline John), though these were not always effective, 'Some characters were perceived as less successful,' argues Newman, 'for violating established patterns ${ }^{\text {'37 }}$ and Companions and Allies recounts how producer Barry Letts decided 'that a clever scientist [like Liz Shaw] was not after all the ideal Doctor Who companion, ${ }^{38}$ because she did not fit the existing dynamic. Mags L. Halliday concludes, 'The problem is that smart, independent women don't make good companions, and that's a painful realization. I don't like the idea that my favorite series has, as a fundamental part of its set-up, no room for the kind of women I want to see. ${ }^{139}$

Rose, as the first new female companion of the reboot, according to Companions and Allies 'would be in many ways the Doctor's equal'40 but this is as much because of the casting of Billie Piper and the shared billing of Eccleston and Piper, as because of the character. Yet even with new, apparently more active and independent, women the structures of the show persist in subordinating female (and male) companions to the Doctor and denying them agency, especially in the endings of their stories. Only Martha chooses to leave the TARDIS herself, but since she does it to heal her unrequited love this agency is still undercut.

So can the Doctor have a female equal? Enter River Song (Alex Kingston). River, like Romana, is potentially an equal-'as close a female version of the Time Lord as audiences have seen in the new series. ${ }^{41}$ She knows more than the Doctor does when they first meet because she is moving in a different temporal direction ('Silence in the Library' 4:8 and 'Forest of the Dead' 4:9). Her warnings about 'spoilers!' reminds us of this regularly and, as David Tennant points out, she even has 'an intimate 
knowledge' of the Doctor himself. ${ }^{42}$ She can pilot the TARDIS and she has a better sonic screwdriver. In addition, she is not constrained by established patterns of behaviour between the Doctor and his female companions. 'She's something new,' Rachel Swirsky notes, 'somewhere between Doctor and companion, human but not ordinary, an inhabitant of liminal space. ${ }^{43}$ Barron calls her a 'future companion'44 but River is not included in Frankham-Allen's 2013 Companions book.

Despite the drawbacks of her sexualized relationship with the Doctor ('All that flirting - do I have to watch this?' complains Madame Kovarian [Frances Barber] in 'The Wedding of River Song' 6:13) she is assertive ('Pretty Boy, you're with me,' she orders the Doctor in her debut episode) and independent ('What, I'm not allowed to have a career, I suppose?' she asks dismissively when he resists her trying to save the world instead of him in 'Forest of the Dead'). She is equally at home as action hero, intellectual, and femme fatale. Alex Kingston says, 'I always wanted to be Sigourney Weaver in Aliens and I guess this is maybe the closest I'll get so I may as well go for it. ${ }^{45}$ A telling comment, this equates River with one of the most famous, if somewhat controversial, female action heroes in science fiction: one who is an active woman not a 'girl' who waits. A newspaper interview describes how 'Kingston steals scenes; she makes off with entire episodes. Matt Smith "gets very jealous," she says, "as I get all the best entry and exit lines." And she does. ${ }^{46}$ Donna often talked back to the Doctor, and for a while River manages to get the last word.

To have an older woman as the love interest is also refreshing. Her interactions with Matt Smith's eleventh Doctor offer, visually, a gap in ages (29 to 48) that replicates but reverses earlier Doctors and their female companions and speaks more broadly to conventional double standards about generation gap relationships. The shadows of Sarah Jane meeting the tenth Doctor decades after she left the TARDIS, and 
Old Amy confronting the eleventh Doctor and a youthful Rory are here given a more positive spin. Some of the press coverage is not entirely comfortable with this reversal, however. 'Moffat calls her Mrs. Robinson,' observes another interviewer, 'after the mother in The Graduate who seduces the son of a family friend, and there's a bit of the cougar in Kingston's on-screen relationship with 28-year-old Matt Smith. ${ }^{, 47}$ Lamont even suggests that 'the chemistry between her and Smith has become almost indecently sexy for a kid's TV show. ${ }^{48}$ Certainly River's typical greeting, 'Hello, sweetie' positions the Doctor as her toy boy. In 'Silence in the Library,' as director Euros Lyn points out, she forces the Doctor into the emotional position usually occupied by the female companion: 'He understands that she could be the love of his life. He understands that even if he doesn't feel it. ${ }^{49}$

However, the necessity for maintaining the Doctor's heroism places limits on River's representation. She appears to have agency but in 'Forest of the Dead' she, like other female companions, chooses to sacrifice herself to save the Doctor and others: she dies in her debut story. Time travel allows her to reappear in subsequent episodes yet the autonomy hinted at in her previous characterization is undercut when a complex backstory is revealed. River's long relationship with the Doctor all happens off-screen and the events we do see ultimately reposition her as child, rather than adult (she is the daughter of Amy and Rory), and wife, rather than lover to the Doctor ('The Wedding of River Song'). Like previous companions, River is potentially an equal, and because she was conceived in the TARDIS she even has some Time Lord characteristics, but her story reveals that she only becomes who she is through the Doctor's intervention. He subverts the conditioning of the Silence, training that renders River a passive tool designed to kill the Doctor. Her story may not be over-yet. But if River is the Doctor's wife, and willingly serves a prison sentence for killing him (when he isn't even dead), 
sometimes sneaking out for romantic liaisons with her husband, she becomes another girl who waited for the Doctor to complete her. McGuire contrasts the arcs of Amy and River in this season: 'Amy waited for her life to begin. River is waiting for hers to come crashing to an end'. ${ }^{50}$ Thus two of the most controversial women in new Who finish in passive positions, waiting, not acting, and paying a high price for their time with the Doctor.

Such unsatisfactory story arcs for potentially strong and interesting female characters are typical, and both Chicks Dig Time Lords and Chicks Unravel Time feature many female writers citing their favourite 'women of DW' and then mentioning how the character's arc was a let-down. Leela's (Louise Jameson) ending (she leaves the TARDIS to marry Andred at the conclusion of 'The Invasion of Time' 15:6) was 'so out of character and disappointing, I actually swore at the television,' recounts Sarah Lotz. ${ }^{51}$ Katharina Freund describes how female vidders redirect their unhappiness at Donna's ending, where she is not able to remember becoming 'the most important woman in the whole wide universe' and saving the world because the Doctor removes her memories of doing so, ostensibly to save her life ('Journey's End' 4:13). 'We're making our own happy ending for the story, because he [Davies] shouldn't have done that to Donna!' 52 After River and Amy, who waited, we now have Clara 'the impossible girl' who eventually reveals, 'I was born to save the Doctor'. This seems to make her the ultimate in a line of Doctor-identified companions.

Booy observes that the 'sexist' elements of the programme were noted at least as far back as the 1980 s during the rise of cultural studies. ${ }^{53}$ Yet until very recently, there has been a dearth of sustained feminist comment in scholarly publishing, as though nobody wants to mention it, or maybe it is thought too obvious to state. The audiences Tulloch interviewed about classic Doctor Who exhibit similar behaviour around gender 
representation. With one group of mothers who watched with their children, he notes that respondents reframe 'the paternalistic and patriarchal position of the Doctor via the consensual notion of family security [and good parenting]. ${ }^{54}$ Later he analyses the careful negotiation of sexism in discussions of the show by middle class male and female fans who choose to divert talk onto different subjects. ${ }^{55}$ In cases like this, affection for and attachment to the show may supersede ideological objections to some of its representations.

Granted, the commercial, industrial and production aspects of TV often produce conflicting demands. And of course, serial television drama is often written and certainly directed by many different people, so that 'messages' about issues like gender are likely to be, if not contradictory, at least less than coherent. Female companions may be primarily written by men, yet they are performed by women, and several scholars have noted how performance can bring a character to life in ways that might be unexpected. Bethan Jones notes how fan discussion around 'The Girl Who Waited' highlights the episode's opportunity for Karen Gillan to really act; both Bradford and Ginn suggest that Elisabeth Sladen's performance of Sarah Jane makes a success of the character, despite bad writing in some instances; and Carole Barrowman and Helen Kang both credit Catherine Tate with creating Donna as an engaging older companion. ${ }^{56}$ More work on how female actors have performed, and perhaps influenced, the shaping of companion characters would help illuminate the problem of gender representation in the series.

Over its long production history, Doctor Who has had very few women directors and even fewer women writers. There have been no female writers since 2010. For a series originally produced by Verity Lambert 'at the time the only female producer at the $\mathrm{BBC},{ }^{57}$ and with a contribution from the cutting edge Delia Derbyshire, this is a 
poor record. While female executive producers, such as Julie Gardner, Head of Drama for BBC Wales at the time of the reboot (2005-2010), and Caroline Skinner (20112013) have played key roles, and Jane Tranter served as BBC's Controller of Drama Commissioning when the reboot debuted, the involvement of these highly-placed women has not positively affected recruitment of female writers and directors to the show. ${ }^{58}$ At the 'Women Who Kick Ass' panel during this year's Comic Con, Michelle Rodriguez suggested one way to get better roles for women, 'We gotta start writing... Writing, and directing, and producing the kind of content we want to see. Because otherwise, nothing's gonna change. ${ }^{59}$ Certainly author Stella Duffy, thinks the same, and commented on Doctor Who's lack of female writers and directors in her blog:

when I see that there are no women writers or directors (that's 16 jobs, not one of them taken by a woman) I am reminded we are nowhere near as equal as we'd like to think we are, nowhere near as 'modern', that a character who cares about the human race above all, is being written and directed in his current incarnation by half of that race. ${ }^{60}$

When challenged on this subject, the BBC can't seem to offer any convincing responses, as Mathilda Gregory outlines in a blog post:

Caroline Skinner, the show's recently departed executive producer, said that it was her intention to see more women writing for Doctor Who. But none has emerged. So I asked producer Marcus Wilson about his plans to improve the balance of male and female writers on the show. 'Due to schedules and other projects, both male and female writers whom we have wanted to join the team 
simply haven't been able to,' he said. 'For us it's about who can write good Doctor Who stories, regardless of gender.' ${ }^{61}$

It seems somewhat essentialist to suggest that male writers, directors and showrunners are incapable of 'feminist' work, or at least of satisfactory gender representation. However, calling for more female writers and directors is not just about whether they can create better female characters and, perhaps, offer new insight into representation of both genders, but is also about redressing a fundamental inequality in the production of the series.

Casting has been another controversial issue, resurfacing when a new actor is selected to play the Doctor. According to Stephen Moffat, female fans don't want a female Doctor: 'Oddly enough, most people who said they were dead against it — and I know I'll get into trouble for saying this — were women, saying, "No, no, don't make him a woman". 62 US writer and producer Jane Espenson believes otherwise, stating in a video interview, 'I think it's time for a woman Doctor. ${ }^{63}$ The BBC has a public service remit which includes promoting diversity, as highlighted in recent debates about casting non-white actors in the series. 'Reflecting the diversity of the UK is a duty of the $\mathrm{BBC}$, and casting on Doctor Who is colour-blind. It is always about the best actors for the roles.' ${ }^{64}$ This 'duty' has not been evidenced in the series, something attracting increasing criticism. Jessica Ebner-Statt, an 11-year old girl writing after the latest casting announcement, would like to see more role models reflecting diversity. 'Doctor Who is a character liked by everyone, who is clever and always saves the world, so I was really hoping for a new female hero who would be a great inspiration to girls everywhere. ${ }^{95}$ 
Fans are becoming more vocal about such issues and one area that has produced gender-oriented scholarship is fandom studies. Williams, and others, discuss the devaluation of feminized fan responses and she, McMurtry and Cherry ${ }^{66}$ all comment on the safe (female) spaces women fans have created for themselves to discuss the series. New Who and its following has certainly challenged the predominantly male fandom of the series that still persists in the UK (though not in other countries). Maybe one of the reasons we don't have more women writers and directors on the new series is because its production is dominated by (male) fan-producers.

In 2010 Wallace speculated how a female Doctor would change the companion/ Doctor dynamic, ${ }^{67}$ and Shoshana Magnet and Robert Smith? were hopeful that the Moffat era would bring a more feminist sensibility to Doctor Who. ${ }^{68}$ Neither has come to pass. Instead, the Moffat era's representation of women (and of sexuality) has produced many challenges and nay-sayers, especially among women viewers. Various speakers at the Walking in Eternity conference talked about how social context has always affected the series. Recent developments are certainly in line with the current backlash against feminism and several news stories and reports over the summer of 2013 that exemplify contemporary debates around the position and representation of women in society and in popular culture influenced this paper.

One such was the controversy over the Bank of England's decision to remove Elizabeth Fry from its banknotes. The consequent erasure of female contributions to UK history prompted Caroline Criado-Perez to start a campaign to replace Fry with another woman, and while this was successful, the rape and death threats received via twitter by Criado-Perez garnered more news coverage than the original campaign. A panel of male comic book writers who discussed, and tried to justify the use of rape in their storylines about female characters attracted attention on the blogosphere. ${ }^{69}$ This story elicited 
several public responses challenging such lazy, sexist thinking and writing, yet I doubt the writers received rape or death threats by twitter. Likewise, while it was inspiring to hear reports from the 'Women Who Kick Ass' panel in Hall H at Comic Con, some of the audience did not respond well to an open discussion of sexism in the industry, especially when the panel ran slightly over time (as most do). Commenting on the hostile atmosphere in parts of the hall, one blogger points out, 'My issue is that the women on this panel who, by definition portrayed strong female characters who more than held their own on-screen with their male co-stars, were silenced for speaking their truths. $^{, 70}$

So, some of this—-most, perhaps—won't be new to those reading. But I feel I have to say it. I cannot celebrate 50 years of Doctor Who, the longest running science fiction show on television, without pointing out that it has serious flaws. Maybe the story of Doctor Who is the story of television. It was also said at the conference that the story of Doctor Who is the story of the BBC. ${ }^{71}$ But for a twenty-first century flagship programme of a public service broadcaster the way Doctor Who represents the British creative industries and the nation itself in a global marketplace is not good enough. Duffy, again:

Try harder. Stop assuming that men can do the job well enough. If women are saying they feel left out (and they do), if women are saying they feel marginalised (and they do), if women are saying they do not see their voices on screen ... Listen to them and do something about it. ${ }^{72}$

How long before Doctor Who completely alienates half its audience and becomes just a show about (white) men, by men, for men? As an academic working on genre and 
representation, as a female viewer of Doctor Who, as the aunt of three girls who love Doctor Who and have grown up with the reboot, and as a science fiction fan, I cannotI will not-keep quiet about this.

I agree 'If we are rabid fans and consumers of pop culture and media, we have to negotiate our love of problematic things in a way that makes sense for us, while remaining true to ourselves. ${ }^{73}$ That doesn't mean keeping quiet about criticisms. Because I'm a rabid fan and consumer, I care deeply, passionately, about what Doctor Who does and how it represents women, as characters, as actors, as writers, as directors and as producers. So, to paraphrase blog site STFU Moffat and with the attitude of Donna Noble I'm saying this because some TV programmes, however much we love them, 'shouldn't be allowed to have their shit left unquestioned. ${ }^{74}$

\section{Films/ Programmes Cited}

Alien (Ridley Scott, 1979).

Buffy the Vampire Slayer (Mutant Enemy/ Kuzui Enterprises/ Sandollar Television/ $20^{\text {th }}$ Century Fox Television/ WB/ UPN, 1997-2003)

Avengers, The (ABC Weekend Television /ITV, ABC, Thames, 1961-69)

Doctor Who (BBC / BBC One, 1963-1989, 1996, 2005-)

Merlin (Shine/ BBC Wales /BBC One, 2008-2013)

Queer as Folk (Red Production Company/ Channel 4, 1999-2000)

Robin Hood (Tiger Aspect/ BBC/ BBC America / Pepper's Ghost Productions/ BBC

One, 2006-2009)

Star Trek (Desilu/ Paramount Television/ CBS, 1966-1969). 


\section{Notes}

1 John Tulloch and Henry Jenkins, Science Fiction Audiences: Watching Doctor Who and Star Trek, Routledge, 1995.

2 Christopher J. Hansen, ed. Ruminations, Peregrinations, and Regenerations: A Critical Approach to Doctor Who, Cambridge Scholars Publishing, 2010.

3 Lorna Jowett, 'Representation: Exploring Issues of Sex, Gender and Race in Cult TV,' in Stacey Abbott, ed. The Cult TV Book, I B Tauris, 2010, pp. 107.

4 Steve Tribe, Doctor Who: Companions and Allies, BBC, 2009, p. 31.

5 John Tulloch and Henry Jenkins, Science Fiction Audiences: Watching Doctor Who and Star Trek, Routledge, 1995, p. 71.

6 Hannah Hamad, 'A Whoniverse of Runaway Brides,' Flow TV, 3 December 2010. http://flowtv.org/2010/12/a-whoniverse-of-runaway-brides/, accessed on 2 August 2013.

7 Tulloch and Jenkins, Science Fiction Audiences, p. 80.

8 Quoted in Jennifer Pelland, 'The Problem With Peri', in Deborah Stanish and L. M. Myles, eds. Chicks Unravel Time: Women Journey Through Every Season on Doctor Who, Mad Norwegian Press, 2012, p. 152.

9 Piers D. Britton, TARDISbound: Navigating the Universes of Doctor Who. IB Tauris, 2011, p. 110.

10 Richard Wallace, ‘’But Doctor?” A Feminist Perspective on Doctor Who,' in Ruminations, Peregrinations, and Regenerations, p. 104.

11 Catherine Johnson. Telefantasy, BFI, 2005, p. 80. 
12 Lynette Porter, 'Chasing Amy: The Evolution of the Doctor's Female Companion in the New Who' in Gillian I. Leitch, ed. Doctor Who in Time and Space: Essays on Theme, Character, History and Fandom, 1963-2012, McFarland, 2013, p. 253.

13 Ibid.

14 Though see Sherry Ginn, 'Spoiled for Another Life: Sarah Jane Smith’s Adventures With and Without Doctor Who' in Leitch, ed., Doctor Who in Time and Space, 2013, pp. 242-52.

15 Britton, TARDISbound, 2011.

16 Rebecca Williams, 'Desiring the Doctor: Identity, Gender and Genre in Online Fandom,' in Tobias Hochsherf and James Leggott, eds. British Science Fiction Film and Television McFarland, 2011, p. 169. See also Claire Jenkins, " "I'm saving the world, I need a decent shirt”: Masculinity and sexuality in Doctor Who,' School of Creative Arts and School of Humanities, University of Hertfordshire, Doctor Who: Walking in Eternity An international interdisciplinary conference celebrating 50 years in time and space, University of Hertfordshire, 3 September 2013.

17 Laura Mead, 'David Tennant's Bum,' in Stanish and Myles, eds. Chicks Unravel Time, 2012, p.143.

18 Andy Frankham-Allen, Companions: Fifty Years of Doctor Who Assistants An Unofficial Guide, Candy Jar Books, 2013, p. 114.

19 Teresa Forde's conference paper offered a rather different take on this idea. Teresa Forde, 'Out of Time: Women, memory and Doctor Who,' Doctor Who: Walking in Eternity, University of Hertfordshire, 4 September 2013.

20 Leslie McMurtry, 'Do It Yourself: Women, Fanzines and Doctor Who,' in Paul Booth, ed. Fan Phenomena: Doctor Who, Intellect, 2013, p. 90. 
21 Antoinette F. Winstead, 'Doctor Who's Women and His Little Blue Box: Time Travel as a Heroic Journey of Self-Discovery for Rose Tyler, Martha Jones and Donna Noble,' in Leitch, ed. Doctor Who in Time and Space, 2013, p. 232.

22 See Jim Leach, Doctor Who, Wayne State University Press, 2009, p. 17.

23 Kim Newman, Doctor Who, BFI, 2005, p. 47.

24 Kate Orman Doctor Who Magazine, quoted in McMurtry, 'Do It Yourself,' 2013, p. 85.

25 Matt Hills, Triumph of a Time Lord: Regenerating Doctor Who in the Twenty-first Century, I B Tauris, 2010, p. 37.

26 Hamad, 'A Whoniverse of Runaway Brides,' 2010.

27 Britton, TARDISbound, p. 117.

28 Hills, Triumph of a Time Lord, p. 38.

29 Britton, TARDISbound, p. 129.

30 'Doctor's Girls’ by mimi-na/ Amy Mebberson. http://mimina.deviantart.com/art/Doctor-s-Girls-46247500, accessed on 2 August 2013.

31 See Hamad for an analysis of the runaway bride figure in the new Who.

32 Britton, TARDISbound, p. 125.

33 See also Ginn, 'Spoiled for Another Life.'

34 Seanan McGuire, 'Waiting for the Doctor: The Women of Series Five,' in Stanish and Myles, eds. Chicks Unravel Time, 2012, p. 240.

35 This is likely to change with the casting of John Hurt and Peter Capaldi as new versions of the Doctor.

36 Newman Doctor Who, pp. 52-3; Chapman, Inside the TARDIS, p. 57.

37 Quoted in Tribe, Companions and Allies, p. 25.

38 Newman, Doctor Who, p. 45. 
39 Mags. L Halliday, 'Seven to Doomsday: The Non-Domestication of Earthbound Doctor Who in Season Seven,' in Stanish and Myles, eds. Chicks Unravel Time, 2012, p. 208.

40 Tribe, Companions and Allies, p. 63.

41 Porter, 'Chasing Amy,' p. 255.

42 David Tennant, 'River Runs Deep,' Doctor Who Confidential Cutdowns 4:9, Disk 6, Doctor Who The Complete Fourth Series, 2entertain, 2009.

43 Rachel Swirksy, 'Guten Tag, Hitler,' in Stanish and Myles, eds. Chicks Unravel Time, 2012, p.257

44 Lee Barron, 'Intergalactic Girlpower: The Gender Politics of Companionship in $21^{\text {st }}$ Century Doctor Who,' in Hansen, ed. Ruminations, Peregrinations, and Regenerations, 2010, p. 48.

45 Alex Kingston, 'River Runs Deep,' 2009.

46 Tom Lamont, "Alex Kingston: "I feel quite motherly towards Matt Smith"' Observer. June 12, 2011, http://www.theguardian.com/tv-andradio/2011/jun/12/alex-kingston-who-luise-miller, accessed on 2 August 2013.

47 Andrew Duncan, 'Doctor Who: Alex Kingston Interviewed,' Radio Times. 27 August, 2011, http://www.radiotimes.com/blog/2011-08-27/doctor-who-alexkingston-interviewed, accessed on 2 August 2013.

48 Lamont, ‘Alex Kingston.’

49 Euros Lyn, 'River Runs Deep,’ 2009.

50 McGuire, 'Waiting for the Doctor,' p. 240.

51 Sarah Lotz, 'For the Love of Tom,' in Stanish and Myles, eds. Chicks Unravel Time, 2012, p. 60 . 
52 Quoted in Katharina Freund, "'We're making our own happy ending!” The Doctor Who Fan Vidding Community,' in Booth, ed. Fan Phenomena, 2013, p. 102. See also Jones.

53 Miles Booy, Love and Monsters: The Doctor Who Experience 1979 to the Present London: IB Tauris, 2012, pp. 105-106.

54 Tulloch and Jenkins, Science Fiction Audiences, p. 111. His respondents are discussing 'Monster of Peladon' (11:4).

55 Ibid, p. 114.

56 Bethan Jones, 'The Girl Who Waited/Survived: Fan rewritings of Amy Pond,' Doctor Who: Walking in Eternity, University of Hertfordshire, 4 September 2013. K. Tempest Bradford, 'The Women We Don't See,' in Chicks Unravel Time, p. 109. Carol Barrowman, 'Time is Relative,' in Lynne M. Thomas and Tara O'Shea eds. Chicks Dig Time Lords: A Celebration of Doctor Who by the Women Who Love It, Mad Norwegian Press, 2010, pp. 18-22. Helen Kang, 'Adventures in OceanCrossing, Margin-skating and Feminist-Engagement with Doctor Who,' in ibid, pp. $38-45$.

57 Chapman, Inside the TARDIS, p. 22.

58 Thanks to Ross Garner for reminding me of the key role played by female producers. Ross Garner, 'Conference Report on Doctor Who: Walking in Eternity - An International Interdisciplinary Conference Celebrating 50 Years in Time and Space,' Jomec@CardiffUniversity, 10 September 2013, http://www.jomec.co.uk/blog/conference-report-on-doctor-who-walking-in-eternityan-international-interdisciplinary-conference-celebrating-50-years-in-time-andspace/, accessed on 11 September 2013. 
59 Quoted in Kate Conway, 'Michelle Rodriguez Made Me Cry at Comic Con,' xojane Jul 26, 2013 http://www.xojane.com/entertainment/michelle-rodriguez-womenwho-rock-panel-comic-con, accessed on 2 August 2013.

60 Stella Duffy, 'Dr [sic] Who and the Missing Women,' 26 March 2013, http://stelladuffy.wordpress.com/2013/03/26/dr-who-and-the-missing-women/, accessed on 2 August 2013.

61 Mathilda Gregory, 'Why Doctor Who Needs More Female Writers', Guardian, 27 March 2013. http://www.theguardian.com/tv-andradio/tvandradioblog/2013/mar/27/doctor-who-female-writers, accessed on 11 June 2013.

62 Quoted in Rosa Silverman, 'Doctor Who: Women Do Not Want To See A Female Time Lord, Says Show's Writer,' Telegraph, 5 Aug 2013, http://www.telegraph.co.uk/culture/tvandradio/doctor-who/10223455/Doctor-Whowomen-do-not-want-to-see-a-female-Timelord-says-shows-writer.html, accessed on 9 August 2013.

63 Jane Espenson in 'Women of Doctor Who,' Just Cos, 17 April 2013, http://www.youtube.com/watch?v=zqD-8uU7ViM, accessed on 9 August 2013.

64 Quoted in Telegraph Reporters, 'Doctor Who "Thunderously Racist”,' Telegraph, 26 May 2013. http://www.telegraph.co.uk/culture/tvandradio/10081580/Doctor-Whothunderously-racist.html, accessed on 11 June 2013.

65 Jessica Ebner-Statt. "'I was really hoping for a new female hero" - an 11 year-old's take on the male Doctor Who,' Telegraph, 6 Aug 2013 http://www.telegraph.co.uk/women/womens-life/10225006/Doctor-Who-I-wasreally-hoping-for-a-new-female-hero-an-11-year-olds-take-on-Peter-Capaldi.html, accessed on 9 August 2013. Courtney Stoker asks is the reason we've never seen a 
female Doctor or a Doctor of color 'because s/he would lose all that power associated with being a white man?' Stoker, 'Maids and Masters: The Distribution of Power in Doctor Who Series Three,' in Stanish and Myles, eds. Chicks Unravel Time, 2012, p. 128.

66 Brigid Cherry, 'ExterminiKnit!: Female Fans and Feminine Handicrafting,' in ed. Booth, Fan Phenomena, 2013, pp. 107-15.

67 Wallace, ‘’But, Doctor?”, p. 116.

68 Shoshana Magnet and Robert Smith?, 'Two Steps Forward, One Step Back: Have We Really Come That Far?' in Thomas and O'Shea eds. Chicks Dig Time Lords, 2010, pp. 154-62.

69 See, for example, MyDearPeabody, 'Mark Millar and Todd McFarlane: Ladies, Comics Aren't For You,' Observation Deck, 10 August 2013, http://observationdeck.io9.com/mark-millar-and-todd-mcfarlane-ladies-comicsarent-f-1095912572, accessed on 22 August 2013.

70 amber.hard.femme 'Comic Con, I love you, but you're bringing me down,' Geeks Out, July 27 2013. http://geeksout.org/blogs/amberhardfemme/comic-con-i-loveyou-youre-bringing-me-down, accessed on 2 August 2013.

71 Mark Adams, 'Commercialisation and Public Service: Historical influences of Doctor Who on the BBC,' Doctor Who: Walking in Eternity, University of Hertfordshire, 4 September 2013.

72 Duffy in Gregory, 'Why Doctor Who Needs More Female Writers.'

73 amber.hard.femme 'Comic Con, I love you.'

74 STFU Moffat http://stfu-moffat.tumblr.com/, accessed on 2 August 2013. 